\title{
Gustaw Herling-Grudziński i legenda o krwi, czyli czy istnieje obowiązek bycia pisarzem żydowskim ${ }^{1}$
}

\author{
Joanna Tokarska-Bakir
}

\begin{abstract}
Abstrakt: Artykuł dotyczy opowiadań średniowiecznych Gustawa Herlinga Grudzińskiego, w których pojawia się wątek legend o krwi. Mimo deklarowanej sympatii dla żydowskich ofiar legendy, oświetlany jest on wybiórczo, wyłącznie z chrześcijańskiego punktu widzenia. Autorka rozważa przyczyny mogące doprowadzić do podobnej deformacji recepcji legend, odnajdując je w opresji państwa narodowego, które pisarzowi pochodzenia żydowskiego nie pozwala być jednocześnie pisarzem polskim.

Wyrażenia kluczowe: Gustaw Herling-Grudzinski; blood libel; koncepcja żydowskiej samonienawiści w ujęciu

Sandera L. Gilmana; żydowski pisarz a polski nacjonalizm
\end{abstract}

$\mathrm{Na}$ ostatnim Festiwalu Brunona Schulza we Wrocławiu w październiku 2014 roku zorganizowano debatę pod tytułem Czy istnieje obowiązek bycia pisarzem żydowskim?, dotyczącą Gustawa Herlinga-Grudzińskiego. Tytułowe pytanie, w domyśle piętnujące ów rzekomy przymus jako oparty na rasistowskich przesłankach, było próbą uniknięcia problemu rzeczywistego poprzez odwrócenie jego perspektywy. W istocie problem stanowiła bowiem ukształtowana przez przedwojenne polskie państwo narodowe niemożność bycia jednocześnie Żydem i pisarzem polskim. Wykluczenia tego doświadczył Gustaw Herling-Grudziński i to właśnie ono ukształtowało jego skomplikowaną tożsamość artystyczną, która będzie przedmiotem moich rozważań.

\section{Przykład Antoniego Stonimskiego}

O konfliktach psychicznych będących produktem podobnych warunków pisano już wielokrotnie. Na przykładzie Antoniego Słonimskiego mówił o nich Adolf Rudnicki:

„W młodości napisał [on] kilka irytujących tekstów, po żydowsku antysemickich. [...] W młodości jego antysemickie wyskoki może były mu potrzebne, może chciał udowodnić sobie samemu, iż pozbył się «garbu»?" (Rudnicki, 1981)2.

To, co Rudnicki nazywa „garbem”, Artur Sandauer opisuje jako „infamię” pochodzenia, o której istnieniu dowiadujemy się na podstawie jego „wstydliwego przemilczania”. Skądinąd ktoś, kto miałby je milczącym za złe, powinien zapoznać się z opisem atmosfery

1 Niniejszy tekst jest rozszerzoną wersją artykułów, które ukazały się wcześniej: Tokarska-Bakir, $2013 a, 2014$.

2 Dziękuję Panu Profesorowi Samuelowi Sandlerowi za zwrócenie mi uwagi na ten ważny tekst. 
Polski międzywojennej w tekście Sandauera O sytuacji pisarza polskiego pochodzenia żydowskiego:

„znaczenie Żydów w kulturze ogólnopolskiej rośnie - paradoksalnie - wraz ze wzrostem antysemityzmu. W ich rękach znajduje się też najpoczytniejszy tygodnik kulturalny «Wiadomości Literackie». Fenomen jedyny w swoim rodzaju: najbardziej lubiani pisarze są jako ludzie najbardziej znienawidzeni. Tuwim boi się wyjść na ulicę, Słonimskiego bije w cukierni Ipohorski, który wielbi poezję Tuwima do tego stopnia, że nie cofa się przed splagiatowaniem Dwóch wiatrów.

Ponieważ znaczna połać kultury polskiej jest teraz wytworem tych ludzỉ nie można być przeciwko nim, nie będąc przeciw własnej kulturze: powstaje zrost antysemityzmu z antyinteligenckością, nurt rasistowsko-plebejski. Przypomina się bajka, jaką z okazji tzw. secesji plebejskiej opowiada u Liwiusza Meneniusz Agrippa: jak to ciało znienawidziło i zbuntowało się przeciwko własnej głowie.

A nienawiść jest rzeczywiście straszna. Gdyby brać wszystkie wyzwiska na serio, można by rzec, że przesłanki do komór gazowych były już gotowe w umysłach tych ludzi" (Sandauer, 1983).

Język polski, którym władali żydowscy Polacy tej epoki, zarezerwował dla nich najbardziej obelżywe słowa. Sandauer przytacza ciągnącą się przez pięć numerów „Gazety Warszawskiej” litanię Stanisława Pieńkowskiego na temat Bolesława Leśmiana:

„Przybył do szanownego grona jeszcze jeden żyd [sic] [...] - B. Leśmian, czyli Lessman. Ten należy do owadziego rodu nekroforów, z upodobaniem grzebiącego się w mogiłach, trupach i zgniliźnie, co zresztą leży w charakterze ducha żydowskiego. [...] Duch żydowski - chce czy nie chce - wnosi z sobą wszystkie swoje właściwości, więc: nihilizm, pesymizm, sceptycyzm, oschłą mózgowość, cynizm, materializm, brud talmudyczny, wszystkojedność i owo lessmanowskie «rozścierwienie od padołów do wyżyn»" (Sandauer, 1983).

Przeliczył się autor tych słów, wróżący Leśmianowi rychłe zapomnienie. Nie pomogła nawet redukcja poety do rzędu bezkręgowców.

Jak w tej atmosferze odnajdował się Antoni Słonimski? Sandauer pisze: „Asymilująca się jednostka musi - zwłaszcza jeśli o dorastającym chłopcu mowa - akceptować ten system wartości, zgodzić się na własną nieurodziwość" (Sandauer, 1983). Słonimski nie ukrywa pochodzenia, ale prezentuje je w możliwej do przyjęcia wersji „postępowo-polsko-patriotycznej", dostosowanej do tego, co od biedy mogło zaakceptować liberalne skrzydło dominującej większości. To jednak wciąż za mało. Zgodnie z logiką samonienawiści ${ }^{4}$ konieczne są dalsze ustępstwa. Kolejnym krokiem jest narodowa samokrytyka, ogłoszenie we „Wiadomościach Literackich” (1924, nr 35) tekstu O drażliwości Żydów, w którym czytamy:

„jedną z kardynalnych i najbardziej charakterystycznych cech żydostwa jest bagatelizowanie najświatlejszych zdobyczy ducha ludzkiego. Żydzi bagatelizują wszystko: kaleczą język, którym mówią, lekceważą czystość mowy, ciała i serca, przeceniają zaś nierozumnie

3 Analogiczna sytuacja powstaje dekadę wcześniej w Niemczech, gdzie w „Deutsch-Judischer Parnass” w roku 1912 Moritz Goldstein pisał: „my, Żydzi, zarządzamy dobrami narodu, który odmawia nam stosownych do tego uprawnień i umiejętności” (https://archive.org/details/MoritzGoldsteinDeutschJudischerParnass191; dostęp: 8 grudnia 2014). Przypis J.T.B.

4 Zob. tekst o koncepcji Sandera Gilmana: Tokarska-Bakir, 2013b. 
istnienie pieniędzy [...]. Dziewięćdziesiąt procent handlarzy żywym towarem to Żydzi” (cyt. za: Sandauer, 1983).

W krótkim opisie, jak w pigułce, zawarte jest wszystko, co przewiduje naukowa teoria stereotypu: pogląd na temat rasy, seksualności, brudu i przyrodzonej skłonności do szaleństwa (Gilman, 1985).

\section{0 tym, co widzialne i niewidzialne}

W tekście Laury Kipnis znajduje się definicja widzialności jako konstruktu społecznego, rozumianego jako społecznie uwarunkowana zdolność selekcji tego, co spostrzegane, z ogółu tego, co jest widoczne. Widzialność (visibility), twierdzi Kipnis, to złożony system nakazów i zakazów, obecności i nieobecności, przerywany epizodami nadwzroczności i histerycznej ślepoty (Kipnis, 1988, s. 158). Trudno o lepszą ekspozycję powyższej definicji niż „gęsta lektura” (close reading, lecture serré) percepcji literackich Gustawa Herlinga-Grudzińskiego. Dzięki niej szczegółowy i zmienny tryb konstruowania narracji możemy porównać z ich nieruchomym obiektem, sześciosekwencyjnym obrazem Paola Uccella Leggenda dell'Ostia profanata, formułując hipotezy odnośnie do społecznych źródeł i nadwzroczności, i przeoczenia 5 .

W niniejszym studium, dla którego jedną z inspiracji stał się artykuł Erwina R. Steinberga i Christiana W. Hallsteina o przemilczeniach w Ulissesie Jamesa Joyce'a (Steinberg \& Hallstein, 2003), chciałabym przyjrzeć się strategii literacko-biograficznej Gustawa Herlinga-Grudzińskiego, zarysowującej się w dwóch jego opowiadaniach, których akcję ulokowano w późnym średniowieczu. Tło każdego z nich stanowią tzw. legendy o krwi w ich wczesnym wariancie, jakim były pomówienia Żydów o profanowanie hostii ${ }^{6}$. W pierwszej części artykułu omawiam problematykę blood libel, w drugiej analizuję interpretacje, które Herling stosuje wobec wizualnych i literackich reprezentacji legendy.

Polska Wikipedia, źródło mało naukowe, ale oddające społeczny konsens ${ }^{7}$, informuje, że Gustaw Herling-Grudziński, „urodził się w spolonizowanej, ale wyznającej judaizm, rodzinie żydowskiej jako Gecel (vel Gustaw) Herling (vel Grudziński), syn Doroty (Dobrysi) z Bryczkowskich i Jakuba (Joska) Herlinga (vel Grudzińskiego)” („Gustaw Herling-Grudziński”, b.d.) ${ }^{8}$. Z perspektywy niniejszego tekstu w przytoczonym zdaniu najważniejszy

$\overline{5}$ Na temat malowidła zob. Katz, 2003; Lavin, 1967. Zob. też Greenblatt, 2006, wkładka barwna po s. 306 i ss. $307-$ 330 .

6 Posługuję się tu terminologią i klasyfikacją tych legend, jaką wprowadziłam w mojej książce zatytułowanej Legendy o krwi. Antropologia przesadu (Tokarska-Bakir, 2008).

7 Dla antropologa poszukującego ukrytej społecznej normatywności Wikipedia, stworzona w oparciu o mechanizm zbiorowej kontroli peer-to-peer, jest nie tyle godnym zaufania źródłem informacji, ile nieocenionym świadectwem społecznej oczywistości (doxa). Omówienie tendencyjności polskiej odmiany Wikipedii zob. „Czy prawica zagarnęła Wikipedię?", 2013.

8 Powyższe dane biograficzne potwierdza biograf Herlinga, Zdzisław Kudelski (Kudelski, 2003). Czytamy tam m.in. „Zdaję sobie sprawę, że taki tytuł może być odczytywany jako szukanie sensacji i tematów modnych. Moja wypowiedź nie będzie w tym akurat punkcie polemiką z Ewą Bieńkowską i jej książką o Herlingu Pisarz i los [(Bieńkowska, 2002); omawiany cytat z Bieńkowskiej dalej w niniejszym tekście - J.T.B.]. Podobnie jak autorkę zdumiewa mnie milczenie Gustawa Herlinga-Grudzińskiego o swoich korzeniach. Czy to zdumienie jest uzasadnione? Sądzę, że tak”. Przeciwną opinię w wywiadzie dla „Rzeczpospolitej” wygłasza Antoni Libera (wytłuszczeniami zazna- 
jest właśnie spójnik „ale”, który odzwierciedlając ideologię państw narodowych zrównujących narodowość z obywatelstwem, przeciwstawia sobie polskość i żydowskość 9 . Spójnik przeciwstawny „ale” streszcza zarazem problemy z tożsamością Herlinga-Grudzińskiego, będące przedmiotem niniejszych rozważań. Stanowią one nierozpoznaną hidden agenda twórczości tego autora, który jak każdy Żyd, szczególnie pisarz żyjący w państwie narodowym, musiał nieustannie dowodzić swojej lojalności i patriotyzmu.

Jako świadkujący stalinowskim zbrodniom narrator Innego świata. Zapiski sowieckie (A World Apart: a Memoir of the Gulag, 1951), jednego z pierwszych literackich obrazów GUŁAG-u, o dekadę wyprzedzającego Jeden dzień z życia Iwana Denisowicza (Odin den' Ivana Denisovitcha, 1962) Aleksandra Sołżenicyna, Gustaw Herling-Grudziński stał się wcieleniem i symbolem polskiej martyrologii na Wschodzie. W konsekwentnie negatywnym portretowaniu wszystkich bez wyjątku żydowskich postaci, jakie występują w jego książce ${ }^{10}$, można widzieć heroiczny wysiłek oddzielania się pisarza od własnej żydowskości, przebiegający według schematu, który Sander L. Gilman opisał w Jewish Self-Hatred (Gilman, 1986). W Polsce żydowskie pochodzenie pisarza, który ochrzcił się w wieku lat 25 jako żołnierz Drugiego Korpusu Polskich Sił Zbrojnych na Zachodzie, przez lata stanowiło pilnie strzeżone tabu. O okolicznościach „wymazywania” żydowskości Herlinga w środowisku „Kultury” paryskiej Irena Grudzińska-Gross pisała obszernie w eseju Podejrzane pochodzenie jako kategoria kultury polskiej (Grudzińska-Gross, 2012, ss. 163-185 ${ }^{11}$. Do zacierania elementów biografii pisarza niepasujących do narracji dominującej przyczynili się przede wszystkim jego biografowie, którzy nawet

czam pytania „Rzeczpospolitej”): „- Tylko dlatego, że jestem na kontrze wobec mainstreamu, jestem bez przerwy stygmatyzowany jako prawicowiec, nacjonalista, niemal faszysta i antysemita! - Antysemita? W czasie wojny pańscy rodzice uciekli z getta. - No i co z tego? Jeśli się jest przeciw mainstreamowi, to choćby było się żydowskim ortodoksem, i tak zostanie się faszystą oraz antysemitą, bo to nieodłączne atrybuty wroga ludu. - Pan ma poczucie tożsamości żydowskiej? - Nie, mam poczucie tożsamości polskiej. Mamy do czynienia z gigantycznym nadużyciem. To samo środowisko, które cały czas mówiło, że tożsamość powinna być przedmiotem wyboru, deklaracji, bo jestem tym, za kogo się uważam, otóż właśnie to samo środowisko próbuje narzucać innym tożsamość żydowską. Pamiętam słynny wywiad w «Gazecie Wyborczej» z Herlingiem-Grudzińskim, któremu przypomniano pochodzenie i żałowano, że nie zajmuje się sprawami żydowskimi. - Czemu panu się ta rozmowa nie spodobała? - Bo Herling dokonał jasnego wyboru - wybrał tożsamość polską, o pochodzeniu nie mówił, a to wyglądało, jakby właśnie ta gazeta chciała zdemaskować go jako Żyda! To sprawa absolutnie osobista, trzeba uszanować taki wybór. - Ma pan teraz prawo, a nawet obowiązek, wybrać sobie płeć, jak każe gender, ale nie ma pan prawa wybrać tożsamości narodowej. - No właśnie, to absurd! Jeśli ktoś nie mówi po hebrajsku ani w jidysz, nie wyznaje judaizmu, to na jakiej zasadzie mamy mówić o tożsamości żydowskiej? - To są kryteria norymberskie" (Mazurek \& Libera, 2013).

9 W porównawczym studium o Polsce i Izraelu pisze o niej następująco Mark Levene: „w oczach niektórych polskich patriotów, a także niektórych patriotów syjonistów, idea przyszłego państwa narodowego nie była oparta na tolerancji czy choćby koegzystencji mniejszości z większością, ale na eliminacji Innego" (Levene, 2000). Zob. Porter, 2001.

10 Zob. np. „Żydzi obsiadali opodal rabina wojskowego o rybich ślepiach i fałdach skóry zwisających z dawnego brzucha”; „maleńki czarny «Jewriej» z Grodna”; „garbaty pokurcz Lewkowicz”; „opasły wieprz Blumen z olbrzymim złotym zegarkiem na przegubie prawej ręki i niezliczoną ilością pierścieni na palcach obu rąk”; „obrzydliwy stukacz Zyskind”; „drapieżny Zelik Lejman”, na skrzypcach odgrywający „swój i swojego narodu los, nie znający granic pomiędzy miłością i nienawiścią”. Albo: „Po klęsce wrześniowej 1939 roku młodzież żydowska z dzielnicy północnej w Warszawie i z gett w małych miasteczkach polskich zajętych przez Niemców ruszyła jak chmura wygnanego ptactwa nad Bug, zostawiwszy starszych na pastwę krematoriów i komór gazowych, a szukając dla siebie ocalenia i lepszego losu w «ojczyźnie proletariatu światowego»”. Żydem jest też człowiek, którego jako tego, któremu się nie przebacza, zapamiętujemy z zakończenia książki. „W jego niepozornej postaci o długich rękach i wykrzywionych kabłąkowato nogach, w ptasiej twarzy uskrzydlonej jakby parą odstających ponad miarę uszu, w czarnych oczach myszkujących niespokojnie wśród sąsiadów” przeciętny polski czytelnik bez trudu rozpozna Żyda.

11 Grudzińska cytowała tam edycję: Jerzy Giedroyć, Melchior Wańkowicz. Listy 1945-1963 („Jerzy Giedroyć, Melchior Wańkowicz", 2000, s. 140). 
juvenalia Herlinga z okresu, gdy komunizował, wkomponowywali w quasi-chrześcijański schemat biograficzny i topograficzny ${ }^{12}$.

W twórczości Herlinga-Grudzińskiego wątek żydowski nigdzie nie został wyraźnie stematyzowany, co niektórych polskich pisarzy skłaniało do niesprawiedliwych uproszczeń. Przykładem może być następująca wypowiedź Henryka Grynberga:

„kiedy jego [tj. Herlinga-Grudzińskiego] żydowskość wyszła na jaw, zaczęto dodawać, że jego rodzina została całkowicie zasymilowana. Co to za tłumaczenie, do tego całkowicie nieprawdziwe, bo to była żydowska rodzina praktykująca. Jego matka, z Bryczkowskich, rzekomo miała być Polką, ale Herling ochrzcił się dopiero w 1944 roku, jakiż więc obrządek religijny towarzyszył jego narodzeniu jak nie obrzezanie? Dziecko nieżydowskiej matki nie jest żydowskie - $\mathrm{i}$ jak piszę w «Pamiętniku» - żaden mohel nie zgodziłby się go obrzezać [...]. I jaka polska matka nadałaby mu imię Gecel? [...] Wie pan, gdyby nie było wojny i okupacji, można byłoby zrozumieć, że pisarz poddany antysemickiej presji chciał uciec od żydostwa. Ale nie przyznawać się do żydostwa po Holokauście, porzucić te ofiary... To smutne, ale niekiedy Żydzi tak bardzo nie chcą być Żydami, że nienawidzą innych Żydów, bo to - jak utrzymują - przez nich są za Żydów uważani i okupują się antysemityzmem kosztem innych Żydów. Z tego punktu widzenia Gustaw to klasyk" (cyt. za: Masłoń, 2012).

Mogłoby się wydawać, że skoro żydowskie pochodzenie nie jest dziś żadną sensacją, poświęcanie mu uwagi nie znajduje wystarczającego uzasadnienia. Pracując nad niniejszym tekstem, doszłam jednak do wniosku, że w twórczości Herlinga kwestia ta nie tylko nie jest marginalna, ale stanowi jeden z głównych problemów, wpływających na ową twórczość tak bardzo, że wręcz deformuje ona autorską percepcję. Nie może być inaczej skoro, powtórzmy za Ireną Grudzinską-Gross,

„mimo Zagłady, czystek etnicznych i powstania Polski jednonarodowej i jednoreligijnej, w sposobie mówienia o pochodzeniu zachowano zadziwiającą ciągłość, sięgającą nie tylko czasów przedwojennych, ale nawet XIX stulecia. Rozpoczęliśmy nowe milenium, ale w odniesieniu do tych spraw wiek XIX ciągle jeszcze trwa” (Grudzińska-Gross, 2012, s. 163).

\section{Legenda o sprofanowanej hostii}

Po raz pierwszy Gustaw Herling-Grudziński wspomina legendę o profanowaniu hostii przez Żydów w opowiadaniu Drugie Przyjście z roku 1961.

„Co dzień oczekiwano Drugiego Przyjścia, a tymczasem palono Żydów i heretyków pomawianych o profanowanie i wyśmiewanie Świętych Hostii. Jeden z takich epizodów zasłyszanych w dzieciństwie namalował w Urbino siedemdziesięcioletni Paolo Uccello. Jego Leggenda dell'Ostia profanata opowiada dzieje Żyda, któremu jakaś kobieta sprzedała wykradzioną z kościoła Hostię; płatek położony na ogniu wytrysnął krwią; Żyda wraz z żoną i dwojgiem dzieci spalono; świętokradczynię powieszono; po dziś zagadką jest siódma tablica cyklu, w której o dusze powieszonej spór toczą para aniołów i para diabłów" (Herling-Grudziński, 1990, s. 145)13.

12 Zob. np. liczne fotografie monstrancji z klasztoru na Świętym Krzyżu, którymi opatrzono jego młodzieńczy utwór pt. Świętokrzyszczyzna, choć trudno zaliczyć to dzieło do literatury katolickiej czy w ogóle religijnej. Por. Herling-Grudziński, 1996.

13 Tekst w zasadzie dosłownie powtórzył w Dzienniku pisanym noca 1997 - zapiska z 15 stycznia 1997 roku (Herling-Grudziński, 2000). 
Do cyklu Uccello Herling-Grudziński powraca trzydzieści lat później w Legendzie o nawróconym pustelniku (1997 rok) (Herling-Grudziński, 2002). Bohaterem opowiadania jest Martin Heinzmünzer, etnolog, syn żydowskich emigrantów z nazistowskich Niemiec, który „szuka różnych wariantów legendy o sprofanowanej Hostii, ponieważ chce dociec, dlaczego Uccello namalował obraz na jej temat"14. Wkrótce Martin zapada na dziwną chorobę i umiera ${ }^{15}$. Narrator, literackie alter ego pisarza, „odwiedza jego grób i wówczas wyobraźnia podsuwa mu obraz rodziny żydowskiej przedstawionej przez Uccella oraz losy rodziny Martina prześladowanej przez nazistów. W 1996 [...] otrzymuje przesyłkę przygotowaną trzydzieści lat wcześniej przez Martina, w której znajduje się nieznana wersja legendy o sprofanowanej Hostii”. W dalszym ciągu opowiadania poznajemy zarówno ów apokryf, jak i „tajemniczy dopisek Martina, z którego można odczytać tylko jedno zdeformowane, jakby przebite piórem słowo - Hostia" (Herling-Grudziński \& Bolecki, 2000, s. 196).

Legendę o nawróconym pustelniku Herling-Grudziński prezentował jako tekst o „problemie prześladowań religijnych", których sztandarem była legenda o sprofanowanej hostii (Herling-Grudziński \& Bolecki, 2000, s. 198). Sądził, że malując swój cykl wydarzeń składających się na legendę, Uccello nie przedstawiał ich z kronikarską wiernością, tylko z dystansem i „mieszanymi uczuciami”. Jego rozmówca, Włodzimierz Bolecki dodawał, że „W warstwie fabularnej legenda o profanacji Hostii jest przecież wariantem wpisanego w najdawniejszą tradycję chrześcijaństwa oskarżenia, że Żydzi ukrzyżowali Chrystusa" (Herling-Grudziński \& Bolecki, 2000, s. 199). Jest to ważne spostrzeżenie, dlatego też przed właściwą analizą udamy się najpierw we wskazanym przez Boleckiego kierunku.

\section{Psychologia wierzeń religijnych}

Dla wierzącego chrześcijanina być może wcale nie Ukrzyżowanie jest najboleśniejszą figurą pasyjną ${ }^{16}$. Istota Golgoty ukazuje się w szyderstwie opisanym w Ewangelii Marka (Mk15, 15-20; Łk 20, 64). Pamięć o upokorzeniu była w niezliczonych wariantach przekazywana przez malarstwo europejskie ${ }^{17}$. Tak opisują je Rozmyślania dominikańskie:

„Przywiodwszy Jezusa za włosy na miesce, gdzie to miał być korunowan i posadzili go na stolcu złem, starym, na ktorym niegdy stare krole korunowano. A to na pośmiech uczynili, mowiąc: «Siedzisz tak, krolu, czekaj korunacyjej albo korony, ktorejś dostojen». A przybiegając, dawali Jezusowi silne policzki. A wziąwszy trześć [trzcinę] prozną, dali mu w rękę, rzekąc: «Krolu żydowski, natychmiast przymierz korunę twej czci godną!». [...]

14 Posiłkuję się tu streszczeniem Włodzimierza Boleckiego w Rozmowie X z cyklu Rozmów w Neapolu (Herling-Grudziński \& Bolecki, 2000, ss. 195-196).

15 „....ze strasznym charkotem, jak gdyby uduszony”, mowa jest też o podejrzeniu „choroby zakaźnej” (Herling-Grudziński, 2002, s. 40).

16 Psycholog społeczna Evelyn G. Lindner uważa, że „raczej zabójstwo jest częścią upokorzenia niż vice versa” (Lindner, 2009, ss. 140-143).

17 Zob. twarze oprawców z Poliptyku Grudziądzkiego, Pomorze Gdańskie, ok. 1390, Grudziądz, kaplica zamku krzyżackiego, tempera na desce, Muzeum Narodowe w Warszawie, nr inw. Śr. 22 (Kochanowska-Reiche, 2000, ss. 90-91, il. 17a). 
I zawiązali oczy Panu Jezusowi szkaradną chustą, popluwając nań, łając sprosnie. A uplotwszy oni groźną korunę jako czapkę, przyszli ku Jezusowi i odkryli oczy i oblicze jego, ukazując mu onę to groźną korunę, rzekąc: "Oto od nas masz, krolu, taką korunę, będziesz ukorunowan»" (Rozmyślania dominikańskie, Konwent Karmelitanek Klauzurowych, Kraków, ms 287, ok. 1530 - cyt. za: Górski, 1965, s. 152).

Plwocina szydzących z Jezusa trafiła na listę arma Christi, co widać na przykładzie obrazu wotywnego z Brzegu (z 1443 roku), gdzie plujący jest Żydem, o czym świadczy biały pileus cornutus („Chapeau juif”, b.d.) na jego głowie.
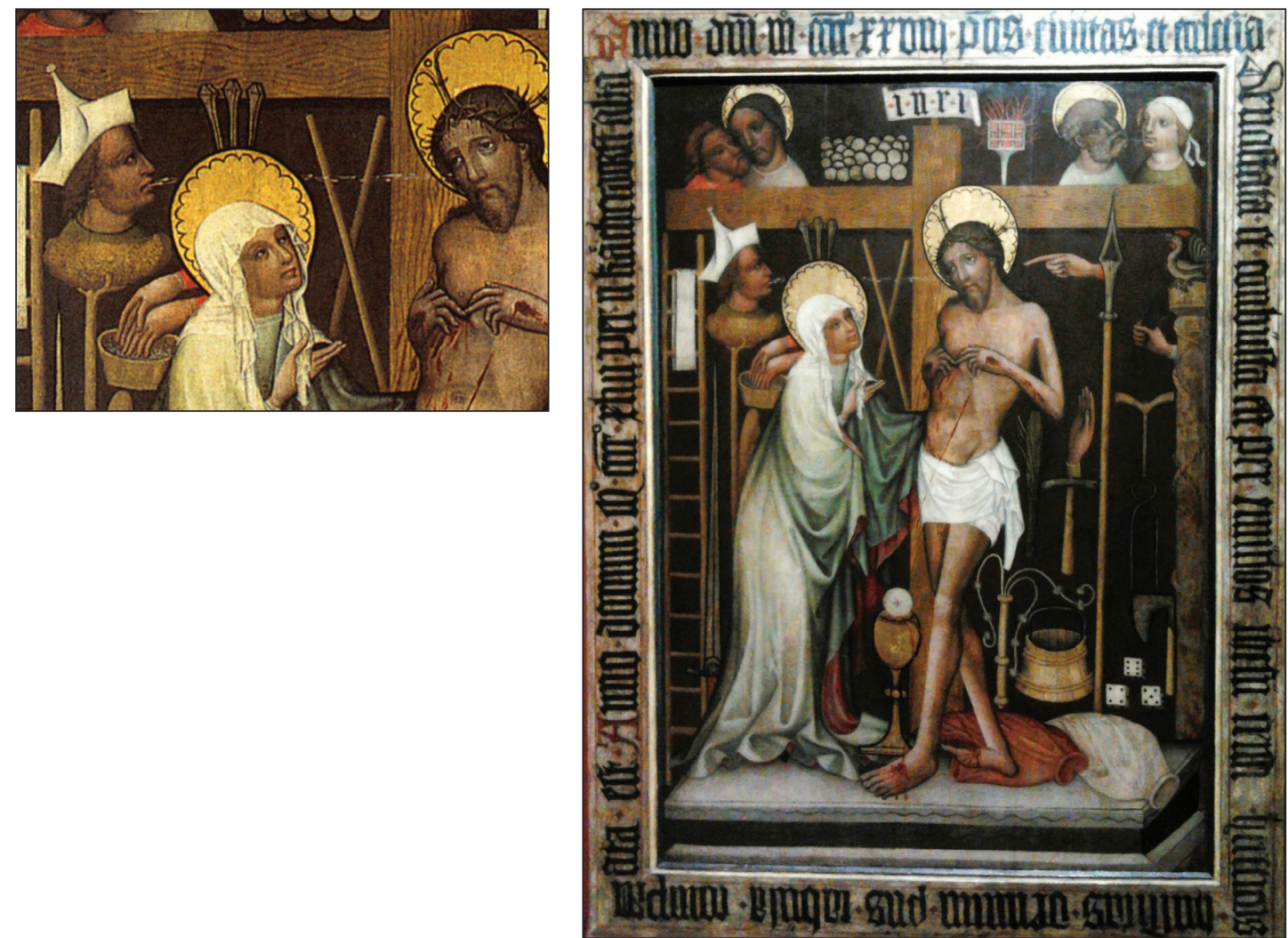

Chrystus Bolesny, obraz wotywny, Śląsk 1443, Brzeg, kościół św. Mikołaja, tempera na desce, Muzeum Narodowe w Warszawie, nr inw. Śr. 343 (reprodukcja za: https//commons.wikimedia.org/wiki/Category: Hussite wars\#/media/ File:Wroc\%C5\%82aw_Christ_as_Man_of_Sorrows.jpg). Głowa w białym spiczastym pileus cornatus zñajduje się pod prawym ramieniem kržżża, tủż óbok żłotej aureoli Marii. Białą przerywaną linią - jak w komiksie - zaznaczono też drogę śliny, która trafia na twarz Jezusa.

Z kolei „szkaradna chusta” stała się atrybutem stroju chrześcijańskich biskupów. O jej symbolice współczesny autor pisze, że „w zastosowaniu do Męki Chrystusa, wyobraża [ona] szyderczą zasłonę, którą Żydzi zarzucili na głowę Chrystusa, aby móc Go opluwać i policzkować (Łk 20, 64)" (Nowowiejski, 1902, ss. 156-157 - cyt. za: Majewski, b.d.).

Identyfikacja z odzieranym z godności Jezusem legła u podstaw fantazji prześladowczych, uruchamiających figurę żydowskich profanatorów hostii. Figurę niemożliwą, bo aby uwierzyć, że kawałek niekwaszonego chleba, od roku 1215 uznawanego przez chrześcijan za Rzeczywistą Obecność, można by ewentualnie profanować, Żydzi musieliby uznać go za coś wartego uwagi. Gdyby chrześcijanie znali Toledot Jeszu, skandaliczny, 
dotyczący genealogii Jezusa żydowski apokryf z VII wieku (w obawie przed prześladowaniami usunięty z Talmudu w wieku XIII) $\left(\right.$ Osier, 1984) ${ }^{18}$, zorientowaliby się w rozmiarze żydowskiej pogardy wobec podobnych idei. Eucharystia, w oczach chrześcijan będąca fizycznym ciałem i krwią Chrystusa, w kręgu kulturowym Morza Śródziemnego stanowiła ekstrakt zmazy (Yuval, 2002) ${ }^{19}$. Jego transgresywna moc odsyła do dwóch bezwzględnych zakazów: zakazu jedzenia ludzkiego mięsa (kanibalizm) i picia krwi (wampiryzm), a jeśli uwzględnić że obecności Jezusa w Eucharystii najczęściej nadawano postać Dzieciątka - także do dzieciobójstwa i pedofagii. Średniowieczne chrześcijaństwo było jednak tak przeświadczone o bezsporności własnej prawdy, że nie brało pod uwagę podobnej różnicy odbioru. Trachtenberg i Langmuir piszą, że legendy o Żydach rzucających w święte wizerunki kamieniami, plujących na nie, kłujących je i tłukących, traktują Żydów jako quasi-chrześcijan, akceptujących ich wyobrażenia o świętości i profanacji, wyobrażenia kłócące się z samą istotą judaizmu ${ }^{20}$. Co Joshua Trachtenberg komentuje następująco:

„Oskarżenie o kaleczenie hostii przez Żydów opierało się na przekonaniu, że oni też uznają dogmat o przeistoczeniu, ten najbardziej osobliwy z sekciarskich dogmatów chrześcijaństwa. Żyd maltański u Marlowe’a nawet zaklina się na corpo di Dio! Obfitość cudów towarzyszących rzekomym zbrodniom żydowskim przeciw chrześcijaństwu, takim jak kaleczenie hostii oraz wizerunków Jezusa i świętych, jak również tzw. mordy rytualne, były nieustannym i nieuniknionym świadectwem, któremu Żydzi nie byli w stanie zaprzeczyć (mimo że zaprzeczali). W miraklach występują nawet kilkakrotnie pobożni Żydzi, którzy uznają cudotwórczą moc św. Mikołaja i czczą jego wizerunek" (Trachtenberg, 1997, ss. 25-26).

Wyrazem podobnych przeświadczeń były legendy o diable oddającym cześć Eucharystii (Tubach, 1981, nr 1602), o klękających wołach i psach (Tubach, 1981, nr 2641), a nawet o kładących się krzyżem świniach (Tubach, 1981, nr 2668).

Tylko realni Żydzi pozostawali niewzruszeni, „złośliwie przekręcając” Pismo, to jest kwestionując chrystologiczne, mesjańskie obietnice, które znajdowali w nim chrześcijańscy egzegecii ${ }^{21}$. Nie przeszkodziło to św. Augustynowi uznać ich za świadków pierwszego sprawowania Eucharystii (Cohen, 1982, ss. 19 n., szczególnie bibliografia s. 20, przypis 2). Trzynastowieczną konkretyzacją tej ich funkcji miała być postać Żyda Wiecznego Tułacza (motyw Q502.1 w: Thompson, 1932). W figurze Ahaswerusa, który stał się epitomem całego narodu żyjącego w rozproszeniu, powraca wątek szyderstwa: Żyd ów miał bluźnić Jezusowi spotkanemu na drodze krzyżowej (Trachtenberg, 1997, s. 25) i właśnie za to, w oczekiwaniu na Drugie Przyjście, niestrudzenie obiegał świat.

\footnotetext{
18 Zob. zwięzły zarys dziejów Talmudu w recepcji europejskiej: Pilarczyk, 2000, ss. 51-52.

19 Także Marcus podaje za źródłami inkwizytorskimi z początku XIV w., że Żydzi mieli świadomość, iż „chrześcijanie jedzą swojego Boga” („christiani comedunt Deum suum”) (Marcus, 1996, s. 253, bibl. przyp. 8). „Wielu poganom Eucharystia musiała się wydawać tysejską ucztą. Misjonarze chrześcijańscy często powoływali się na słowa Jezusa w Ewangelii Jana (J 6,53-55): «Jeślibyście nie jedli ciała Syna Człowieczego i nie pili krwie jego, nie będziecie mieć żywota w sobie. Kto pożywa ciała mego i pożywa moją krew, ma żywot wieczny, a ja go wskrzeszę w ostatn dzień. Albowiem ciało moje prawdziwie jest pokarm, a krew moja prawdziwie jest napój»” (Cohen, 1982, s. 8, tam też bibl.). Por. Tokarska-Bakir, 2008, ss. 169 n.

20 Szerzej na ten temat Langmuir, 2002, ss. 297-298.

21 Na temat oskarżeń Żydów o złośliwe przekręcanie Pisma Świętego zob. Trachtenberg, 1997, s. 25.
} 


\section{De puerulo iudeo - '0 żydowskim chtopczyku'}

Spór chrześcijaństwa i judaizmu to spór o prawdę objawienia. Właściwie aż do pojawienia się ekumenizmu w wieku XX, z chrześcijańskiego punktu widzenia jedynym wyjściem z sytuacji była zbiorowa konwersja Żydów. O ile późniejsze legendy, jak ta o Ahaswerusie czy o znaku Kaina (motyw Q556.2 w: Thompson, 1932)22, piętnowały cały lud, na którego „nawrócenie” przestano już liczyć, wcześniej, w późnej starożytności (np. u Grzegorza z Tours, † 594), spotykamy legendę o żydowskim chłopcu (V363 w: Thompson, 1932)23, w której postawa Żydów wobec konwersji zaczynała się dopiero różnicować - w każdym razie w oczach oczekujących jej chrześcijan. Budująca historia cudu eucharystycznego w późnych (sądząc po wzmiance o franciszkanach) wariantach, sytuowana „w mieście, które nazywa się Wrocław”, dotyczy żydowskiego chłopca, który wraz z kolegami chrześcijanami wybiera się do kościoła ${ }^{24}$. Na ołtarzu dostrzega jaśniejącą kobiecą postać z dzieckiem na ręku. Kapłan bierze od niej to dziecko „i rozdziela je między wszystkich wiernych, każdemu dając cząstkę". Żydowski chłopiec też otrzymuje od księdza kawałek ciała i zabiera je ze sobą do domu. Tam naraża się na gniew ojca, który

„rozpala wielki ogień w piecu i, zamknąwszy drzwi domu, wpycha syna do środka, aby się spalił. Ale matka chłopca, widząc to, zaczyna głośno krzyczeć. Zbiegają się ludzie, wyważają drzwi i wyciągają chłopca z płonącego pieca. Gdy dziwili się, że nic mu się nie stało i że nie tknął go ogień, on im odrzekł z radością: «Tę moją panią, którą widziałem w kościele, jak stała z dzieciątkiem na ołtarzu, ujrzałem siedzącą w piecu. Wzięła mnie na ręce, strząsnęła ze mnie płomienie i włożyła na mnie białą szatę, a ogień nie zrobił mi krzywdy». Usłyszawszy to wszyscy, wznosząc ręce i głosy ku niebu, chwalili Jezusa Chrystusa i Jego pełną chwały Matkę Maryję. Zażądali od Żyda cząstki ciała, danej mu przez chłopca. Chrześcijanie z wielkim płaczem i dziękczynieniem zanieśli ją uroczyście do kościoła. W nim Pan dla uczczenia swego ciała sprawia wiele cudów. Księża zaś ochrzcili chłopca wraz z matką i licznymi Żydami, którzy wszyscy uwierzyli w Jezusa. Ojciec jednak, któremu diabeł zatwardził serce, nie dał się ochrzcić. Miejski sędzia, związawszy mu ręce i nogi, wrzucił go do pieca, który on wcześniej rozpalit, by zgładzić własnego syna. Natychmiast strawił go ogień. Matka i syn wraz z innymi, którzy się ochrzcili, wstąpiwszy do zakonu franciszkanów i franciszkanek, gorliwie służyli Chrystusowi i Jego Matce Maryi i doprowadzili swe życie do dobrego końca" (cyt. za: Dobrowolski, 1928, ss. 42-43).

W legendzie eucharystycznej przed Żydami rysuje się prosty wybór: droga zbawienia dla matki oraz syna i droga wiecznego potępienia dla ojca. Równie wyraźnie rysuje się w niej polemiczna, misyjna intencja, adresowana nie tylko do Żydów. Bohaterką jednej z legend wspomnianych przez Index exemplorum jest chrześcijanka kuszona przez diabła, by sprawdzić, czy Bóg jest naprawdę obecny w Eucharystii. Przynosi ją w chustce do domu i wrzuca do pieca. „Słyszy wówczas dobiegający stamtąd głos chłopca wzywającego matkę i widzi Dziewicę, ratującą Dzieciątko Jezus" (Tubach, 1981, nr 2685 w Index exemplorum, z odsyłaczem do 2661, 2689).

22 Zob. także Q556.1: „curse for participation in Crucifiction” (Thompson, 1932).

23 Na temat legendy o żydowskim chłopcu zob. Rubin, 1999, rozdz. From Jewish Boy to Bleeding Host.

24 Tekst łaciński w: Dobrowolski, 1928, ss. 42-43; przekład Mikołaj Szymański. 
Chrześcijańskiego adresata ma też legenda odnotowana przez Index exemplorum pod numerem 2689: „hostia przemieniona”. Występuje ona w trzech wariantach:

- (a) jako „hostia przemieniona w krwawiące ciało”: „kobieta [chrześcijanka] położyła konsekrowaną hostię w szkatułce, która zaczyna jaśnieć w nocy; otwarłszy szkatułkę, odkrywa, że hostia stała się krwawiącym ciałem"25;

- (b) „hostia przemieniona w krew”: „Żyd przekłuwa hostię nożem; wypływają strumienie krwi"26;

- (c) „hostia przemieniona w Dzieciątko Jezus”27.

Tylko w drugim wariancie legendy występuje wzmianka o Żydach, torturujących opłatek w poszukiwaniu Rzeczywistej Obecności. Odczuwający repulsję wobec idei „Świętego Ciała i Krwi" starozakonni stanowią tu w istocie porte parole chrześcijan, którym od ustanowienia dogmatu o Rzeczywistej Obecności będzie stale towarzyszyć pokusa wystawiania Boga na próbę ${ }^{28}$, a także niezwykle wprost rozwinięta magia eucharystyczna (zob. Ganszyniec, 1959; Tokarska-Bakir, 2008, ss. 139-142). W średniowiecznych miraklach jest odgrywany cały schemat wątpienia, wyrażający się w fantazjach na temat poddawania hostii „próbom inicjacyjnym”: paleniu, pieczeniu, gotowaniu, mieleniu w żarnach, topieniu w wodzie lub dole kloacznym, kłuciu, porzucaniu na polu lub w błocie (Tokarska-Bakir, 2008, ss. 212-227 i 228-231) ${ }^{29}$. Niezależnie od licznych antysemickich zastosowań legendy eucharystyczne były przede wszystkim orężem w zwalczaniu zwątpienia we własnych szeregach, bronią w sporach o Eucharystię, w polemikach z husytami ${ }^{30}$, protoprotestantami, a w końcu także protestantami. Właśnie w okresach ożywienia tych polemik odkurzano postać złej chrześcijanki, która wydaje hostię Żydom $^{31}$.

Od ponad wieku fenomen legend o krwi stanowi przedmiot dociekań historyków, antropologów, psychologów i folklorystów. Konkluzywnym opracowaniem w tej dziedzinie jest studium Alana Dundesa zatytułowane The Ritual Murder or Blood Libel: A Study of Anti-Semitic Victimization through Projective Inversion (Bronner, 2007, ss. 386-409). Folklorysta amerykański stawia w nim tezę, że legenda o żydowskich zamachach na chrześcijańskie świętości, szczególnie zaś mit o tzw. mordzie rytualnym, jest zagadnieniem źle badanym. Nie stanowi bowiem problemu historycznego, lecz psychologiczny (Bronner,

\footnotetext{
25 Dla wariantu nr 2689a Tubach podaje około 20 egzempli, co pokazuje popularność wątku w średniowiecznym kaznodziejstwie (Tubach, 1981).

31 Zob. np. oskarżenie Żydów sochaczewskich w 1556 roku, utrwalone w anonimowej broszurze protestanckiej pod wymownym tytułem $O$ sochaczewskim wymęczonym a wypalonym na Żydzie Bogu i o fałszywych jego cudach (zob. Guldon \& Wijaczka, 1995, s. 86). Miri Rubin przytacza też dokument z połowy XIV w. dotyczący dwóch studentów, którzy ukradli cztery hostie w kościele w czeskich Modřicach z zamiarem późniejszej ich sprzedaży Żydom z Brna (Żydzi w porę dali o tym znać miejscowym władzom). Studentów skazano jako heretyków na stos, a w sentencji wyroku orzeczono, że „pragnienie sprzedaży powinno zostać osądzone surowiej niż sam akt kradzieży”. Źródła omawia Miri Rubin (Rubin, 1999, przyp. 134).
} 
2007, s. 394). Dundes rozpoznaje w legendzie mechanizm inwersji projekcyjnej32. Ciekawość dręcząca chrześcijan od chwili, gdy IV Sobór Laterański wprowadził dogmat o Rzeczywistej Obecności, została wyprojektowana na Żydów ze wszystkimi konsekwencjami.

\section{Schemat Legendy o sprofanowanej hostii - historia profanacji paryskiej}

Przedmiotem studiów Gustawa Herlinga Grudzińskiego w Legendzie o nawróconym pustelniku, komentowanej też dwukrotnie w Dzienniku pisanym nocą3 i Rozmowach w Neapolu, jest wariant „b” legendy nr 2689 z Index exemplorum („hostia przemieniona w krew”) połączony z transpozycją Legendy o żydowskim chłopcu (V363 z indeksu Thompsona). Pisarz powraca w niej do obrazu Uccella, wzmiankowanego już w Drugim Przyjściu.
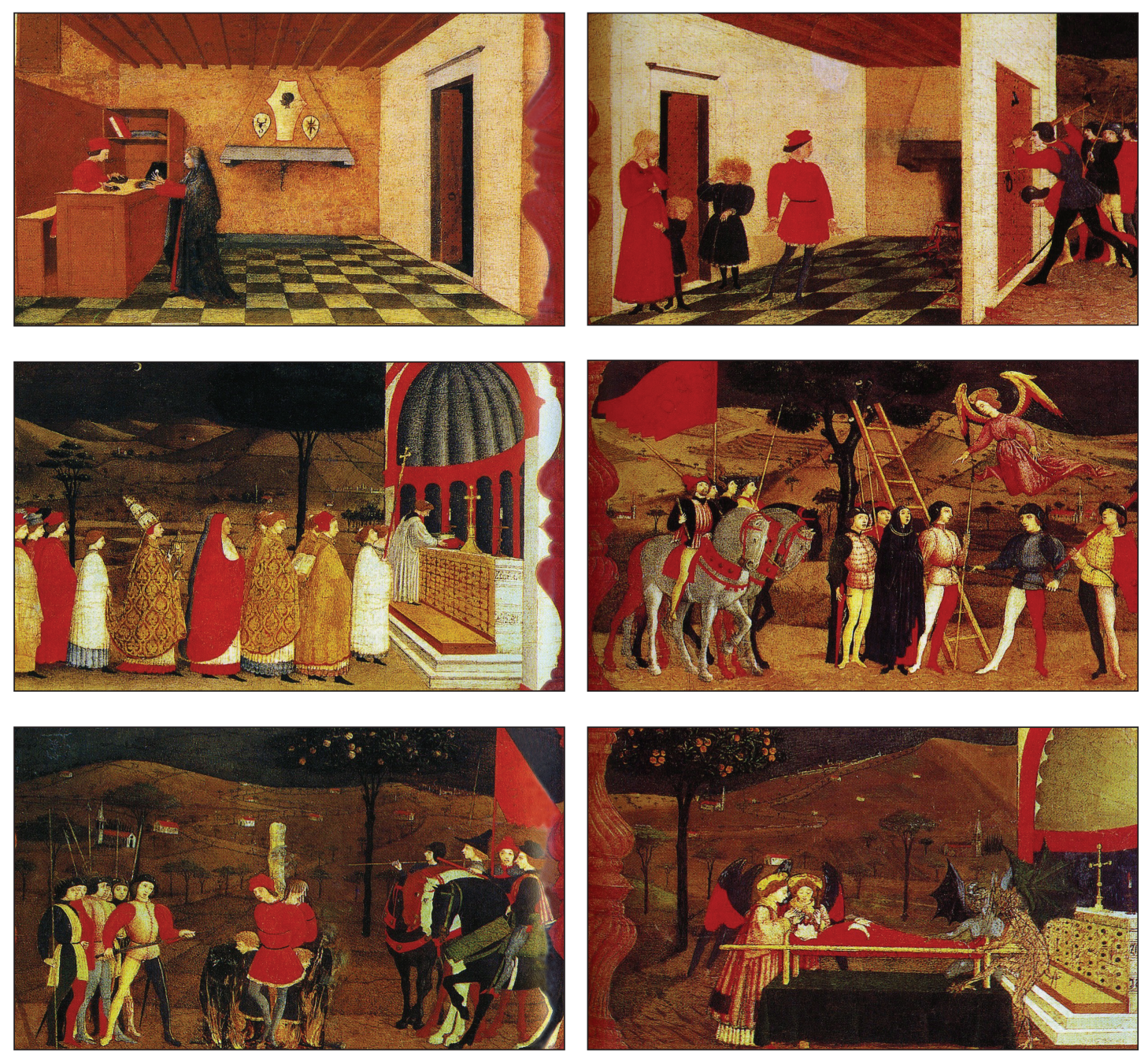

Paolo Uccello, Leggenda dell'Ostia profanata, predella ołtarza bractwa Corpus Christi, ok. 1465-1468, Galleria Nazionale della Marche, Palazzo Ducale, Urbino (za: https://fr.wikipedia.org/wiki/Le_Miracle_de_l'hostie_profan\% (3\%A9e).

32 „Projective inversion refers to a psychological process in which A accuses B of carrying out an action which A really wishes to carry out him or herself" (Bronner, 2007, s. 395).

33 Oprócz wzmianki w Dzienniku pisanym noca 1997-1999 (Herling-Grudziński, 2000) Herling pisze na ten temat także w Dzienniku pisanym nocą 1973-1979 (Herling-Grudziński, 1995, ss. 100-114). 
Choć obraz Uccella namalowany pomiędzy rokiem 1465 i 1468 wydaje się osadzony w realiach włoskich, jest najsłynniejszym malarskim przedstawieniem domniemanej profanacji hostii paryskiej z końca XIII wieku, która ustanowiła wzór oskarżeń Żydów o tę zbrodnię ${ }^{34}$. Wielokrotnie odnotowywali ją antysemiccy pisarze staropolscy, na przykład Szymon A. Hubicki w dziele z roku 1602:

„Roku 1290 tráfiło sie w Páryżu, że niewiástá iedná zá podwiedźieniem Zydowskiem, ktory iey zastáwne rzeczy wroćić dármo obiecował, Sákrámentu dostáłá y Zydowi wydáłá. Wźiąwszy Zyd Sákráment, palił go ná pátelli, ktory iż sie nic nie mienił, puginałem go przekłoł, ták iż krew z niego ćiekłá; co gdy sie zátáić nie mogło, porwano onego Zydá y skarano y z onemi, ktorzy ták srogiego uczynku winni byli, á dom iego ná Kośćioł obrocono y przezwisko Salvatoris bullientis, to iest Zbáwićielá wráiącego dano. W ktorym y podźiśdźień onę przebodzoną Hostyą y z puginałem chowaią" (Hubicki, 1602).

Oderwana od realiów francuskich opowieść równie dobrze sprawdzała się w realiach jak polskich, tak włoskich. Zawdzięcza to konstrukcji opartej na uniwersalnym, dobrze wypadającym w miraklach eucharystycznych schemacie ${ }^{35}$ : szkodzenie - walka - zwycięstwo / zdemaskowanie Antagonisty - ukaranie ${ }^{36}$, gdzie szkodzeniem jest zdobycie i torturowanie hostii przez Żydów, zwycięską walką boskiego Bohatera - krew z niej wypływająca, potwierdzająca Rzeczywistą Obecność, co jest równoznaczne ze zdemaskowaniem profanatorów (zbiorowy Antagonista) i stanowi wstęp do ich ukarania.

W najbardziej zbliżonym do oryginalnego kontekstu De miraculo hostiae a Judaeo Parisiis... anno Domini... MCCXC37 czytamy, że zdarzenie miało miejsce w Wielkim Tygodniu roku 1290. Mowa jest o żydowskim lichwiarzu, który skusił służącą u niego (albo też zadłużoną) chrześcijankę z parafii Saint-Jean-en-Grève, by przyniosła mu hostię z komunii wielkanocnej.

„Jako że pewna kobieta bardzo uboga (tenuissimae fortunae) oddała swoją odzież pod zastaw Żydowi w zamian za pożyczenie jej 30 szylingów [...], Żyd obiecał zwrócić ją jej darmo, jeśli przyniesie mu tę rzecz, którą ona nazywa swoim Bogiem"38.

„Kobietę bardzo ubogą” tekst kreuje dalej na pomocnicę Antagonisty, określając ją mianem zachłannej (avara mulier) i przypisując próżność (w Wielkanoc chciała ona zabłysnąć przed sąsiadkami: ut inter vicinas cultior appareat). Następująca dalej funkcja szkodzenia rozpoczyna się od sformułowania celu profanacji. „Teraz się okaże, ile warte są brednie, które opowiadają o niej [tj. o hostii] chrześcijanie"39 - mówi zastawnik

34 Zob. opracowanie faktograficzne narracji i bibliografia wariantów w: Rubin, 1999, s. 41, przyp. 3. Powtarzane przez najważniejszych pisarzy antysemickich ery staropolskiej - księży Przecława Mojeckiego, Stefana Hubickiego i Stefana Żuchowskiego - warianty narracji o profanacji hostii paryskiej ustanowiły także podstawę polskich narracji o krwi (zob. Tokarska-Bakir, 2008, ss. 125-137).

35 Zob. np. La rappresentatione d'uno miracolo del corpo di Christo (mirakl), Florencja ok. 1500 (Kristeller, 1968 , nr 48 cyt. za: Schreckenberg, 1996, il. 267b).

36 Dla uproszczenia pomijam komplikacje związane z pierwszą (zakaz/złamanie zakazu) i ostatnią (wesele) częścią schematu narracyjnego, który analizuję w Legendach o krwi, cz. 1, rozdz. 1 (Tokarska-Bakir, 2008, ss. 97-136).

37 Na temat samego tekstu: Jordan, 1989, ss. 193-194; bibliografia Rubin, 1999, s. 213, przyp. 3.

38 „...gratis redditurum se Judaeus pollicetur, si rem illam, quam mulier Deum suum asserebat, afferet” („De miraculo hostiae a Judaeo Parisiis anno Domini MCCXC multis ignominiis affectatae", 1968).

39 „Sciam, inquit, an vera sint quae de re hujusmodi insani garriunt Christiani” („De miraculo hostiae a Judaeo Parisiis anno Domini MCCXC multis ignominiis affectatae", 1968). 


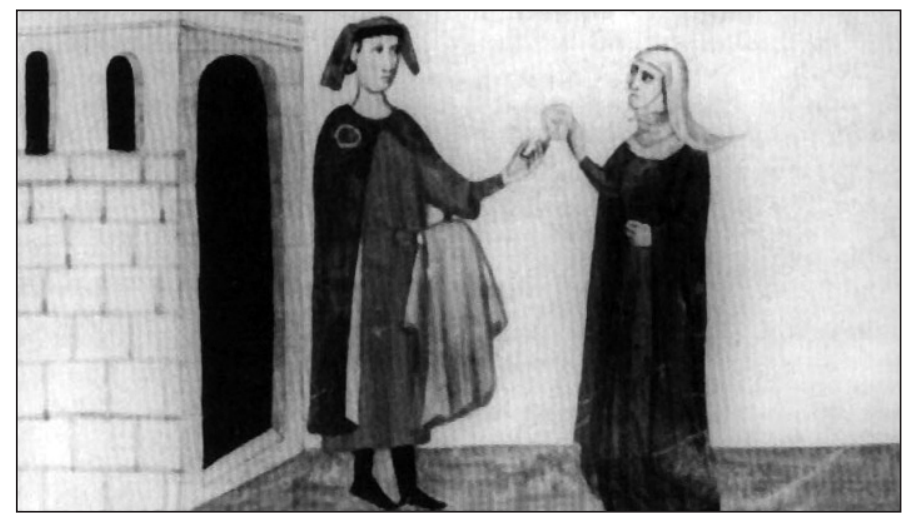

Chrześcijanka wręcza żydowskiemu lichwiarzowi-zastawnikowi hostię, aby odzyskać zastawioną suknię. Zob. rota żydowska na ramieniu postaci z lewej. Miniatura z Kroniki florenckiej Giovanniego Villani (Chroniche di Giovanni, Matteo e Filippo Villani, 1320, Biblioteca Apostolica Vaticana, Chigi, rkps LVIII, k.149v - za Magnani, 1936, fig. XL. Zob. też Schreckenberg, 1996, s. 273; Rubin, 1999, s. 43).

żydowski, gdy tylko uzyskuje opłatek. Walka, będąca faktycznie gigantomachią, rozpoczyna się od tortur zadawanych przez Antagonistę, z których krwawiący Bohater - corpus Christi - wychodzi zwycięsko.

Zanim szczegółowo prześledzimy cykl miniatur Uccella, przyjrzyjmy się punktowi kulminacyjnemu opowieści, przedstawionemu na ilustracji jednego z mirakli eucharystycznych poświęconemu temu zdarzeniu, pt. La rappresentatione d'uno miracolo del corpo di Christo, Florencja, ok. 1500. Jest na niej scena przypiekania hostii przez Żydów na tzw. patelli:

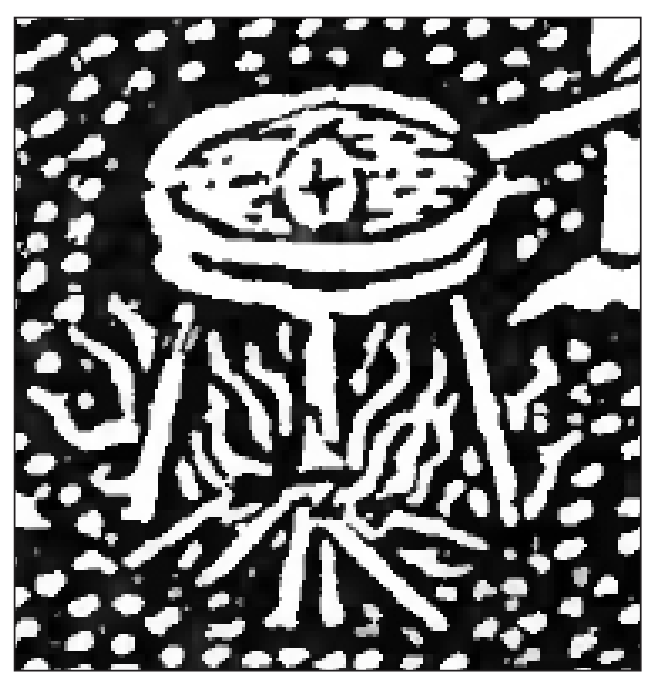

Patella z torturowanymi na ogniu, a jednocześnie kłutymi sztyletem hostiami współwystępuje tu, zwyczajem sztuki symultanicznej, z przedstawionym po lewej stronie wydarzeniem wcześniejszym, gdy chrześcijanka sprzedaje hostię żydowskiemu zastawnikowi; wyznanie kobiety rozpoznajemy po braku roty - tradycyjnej oznaki żydowskiej, którą oznaczono stroje wszystkich pozostałych uczestników sceny. 


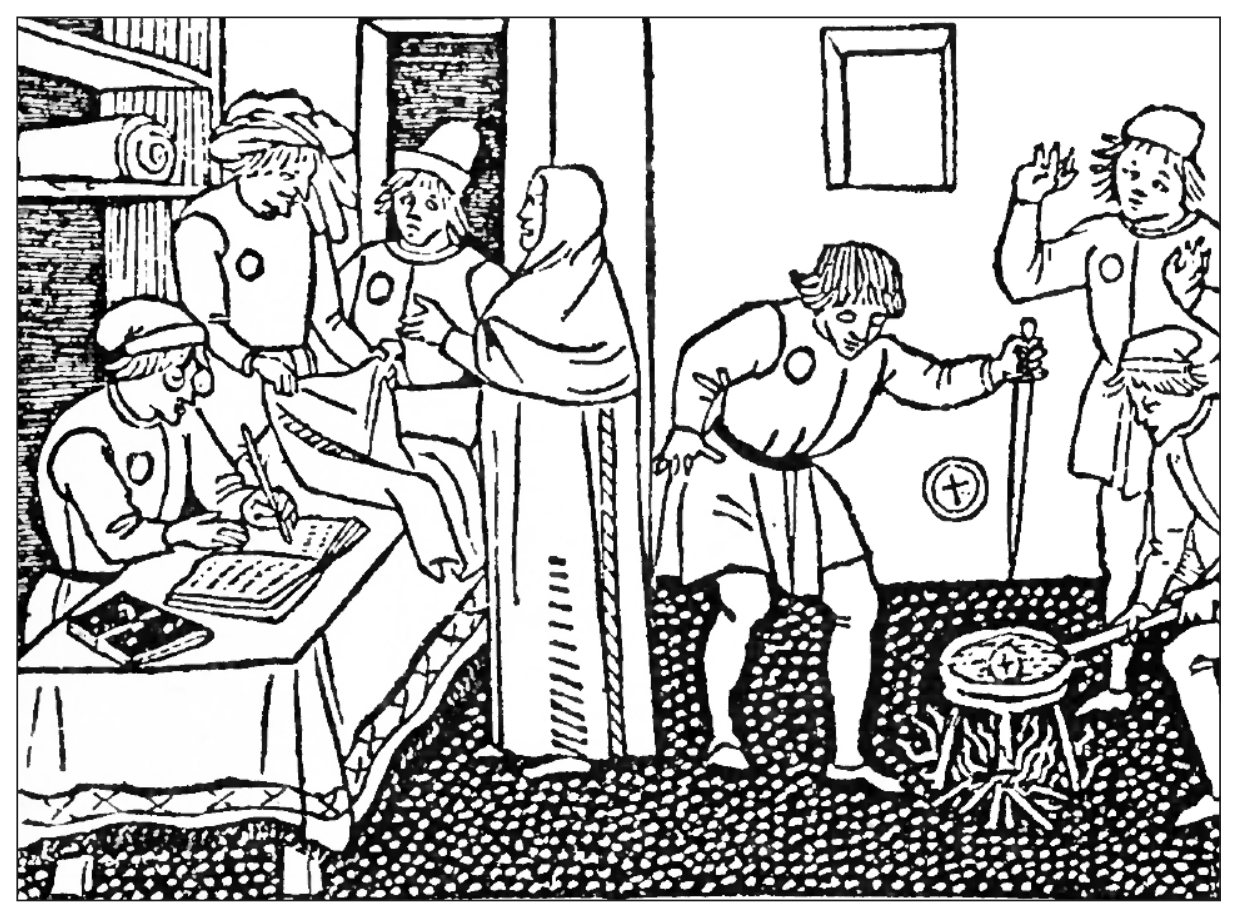

Hostie (krążki z krzyżykiem) kłute nożami i przypiekane nad ogniem na patelli; La rappresentatione d'uno miracolo del corpo di Christo (mirakl), Florencja ok. 1500 (reprodukcja za: Pollard, 1902, s. 29 - http://scans.library.utoronto.ca/pdf/2/37/ oldpicturebooksw00polluoft/oldpicturebook sw00polluoft.pdf. Por. Kristeller, 1968; Schreckenberg, 1996, s. 267b)

Dopiero po takim wstępie możemy rozpocząć analizę cyklu miniatur Uccella w kadrze opowiadania Herlinga-Grudzińskiego. Narrację, w którą się układają, prześledzimy, porównując opisy Miri Rubin, badaczki historii corpus Christi (Rubin, 1999, s. 148), i autora Legendy o nawróconym pustelniku (Herling-Grudziński, 2002, ss. 34-35) ${ }^{40}$. W odpowiednich kolumnach zaznaczam kolejność, w jakiej pojawiają się one w tekstach obojga autorów. U Herlinga jest to kolejność 1-3-2-4-5-6 w stosunku do sekwencji zanotowanej przez Rubin.

\begin{tabular}{|l|l|l|l|}
\hline \multicolumn{1}{|c|}{ Rubin } & & \multicolumn{1}{c|}{ Herling-Grudziński } \\
\hline 1 & $\begin{array}{l}\text { „Scena, w której } \\
\text { kobieta i żydowski } \\
\text { zastawnik wymie- } \\
\text { niają hostię na } \\
\text { suknię”. }\end{array}$ & 1 & $\begin{array}{l}\text { „Sklep wysnuty z ówczesnych zwyczajów. Przestronny, z brą- } \\
\text { zowo-białą szachownicą podłogi, sufit pręgowany belkami, } \\
\text { wypukły i zdobny trójkąt na bocznej ścianie, gdzie przypusz- } \\
\text { czalnie znajdowat się kominek, gdzie drzwi, czarny kwadrat } \\
\text { okna za kontuarem sklepikarza. Sklepikarz żydowski stoi za } \\
\text { kontuarem, ubrany na czerwono, wyciąga rękę. Po co? Po prze- } \\
\text { ciwnej stronie kontuaru stoi kobieta w długiej brunatnej sza- } \\
\text { cie, w palcach prawej ręki trzyma biały krążek. To wykradziona } \\
\text { z kościoła Hostia, przyniesiona (rzekomo) do sprzedania wła- } \\
\text { ścicielowi sklepu”. }\end{array}$ \\
\hline
\end{tabular}

40 Opowiadanie powstało pomiędzy lipcem i sierpniem 1997 roku; pierwodruk w tygodniowym dodatku do „Rzeczpospolitej” pt. „Plus Minus” z 4 października 1997 roku. 


\begin{tabular}{|c|c|c|c|}
\hline 2 & $\begin{array}{l}\text { „Scena domowa } \\
\text { [w domu żydow- } \\
\text { skiego zastawnika], } \\
\text { w której hostia } \\
\text { ułożona na paleni- } \\
\text { sku krwawi w obec- } \\
\text { ności jego stra- } \\
\text { pionej żony, syna } \\
\text { i córki, podczas gdy } \\
\text { grupa chrześcijan } \\
\text { wyłamuje drzwi na } \\
\text { widok krwi spływa- } \\
\text { jącej po ścianie”. }\end{array}$ & 3 & $\begin{array}{l}\text { „Do drzwi zamkniętego sklepu dobijają się strażnicy, jeden to- } \\
\text { moce w nie siekierą. Po tamtej stronie drzwi oczekują strwo- } \\
\text { żeni sklepikarz żydowski i jego żona, oboje w czerwonych } \\
\text { strojach; młodsze dziecko tuli się do matki, starsze, bardzo } \\
\text { kędzierzawe piąstką powstrzymuje łzy, napływające do oczu; } \\
\text { niebawem drzwi zostaną wyłamane”. }\end{array}$ \\
\hline 3 & $\begin{array}{l}\text { „Procesyjne prze- } \\
\text { niesienie cudownej } \\
\text { hostii na ołtarz } \\
\text { w apsydzie, dziwna } \\
\text { scena nocna”. }\end{array}$ & 4 & $\begin{array}{l}\text { „Kopuła niewidocznego kościoła osłania ołtarz. Ksiądz pochy- } \\
\text { la się nad ołtarzem, za nim kościelny wznosi krzyż na drąż- } \\
\text { ku; w głębi znowu krajobraz Marche, tym razem powleczony } \\
\text { wczesnym zmrokiem; na niebie sierp księżyca, dziesięć osób } \\
\text { ustawionych w jednym rzędzie posuwających się w procesji } \\
\text { do ołtarza; ksiądz szykuje się do rekonstrukcji sprofanowanej } \\
\text { Hostii”. }\end{array}$ \\
\hline 4 & $\begin{array}{l}\text { „Egzekucja na } \\
\text { chrześcijance przez } \\
\text { powieszenie”. }\end{array}$ & 2 & $\begin{array}{l}\text { „W tle krajobraz Marche, pokratkowany działkami uprawnymi, } \\
\text { pagórkowaty. Na pierwszym planie wysokie i proste drzewo, } \\
\text { z przystawioną drabiną. Nie widać sznura, ale wiadomo, że za } \\
\text { chwilę będzie przerzucony przez górny, liściasty konar. Drzewo } \\
\text { jest osią tablicy. Po prawej stronie jeźdźcy na pięknych ruma- } \\
\text { kach (specjalność Uccella), jeden trzyma w rękach czerwoną } \\
\text { chorągiew, drugi włócznię opartą na sztorc o strzemię, jest ich } \\
\text { czterech. Po prawej stronie pięciu uzbrojonych pieszych w ko- } \\
\text { lorowych ubiorach; w dali wieżyczka kościoła. Świętokradczy- } \\
\text { ni, w czarnej teraz szacie, oparta o drabinę, czeka na wyko- } \\
\text { nanie wyroku. Z ciemnozielonego nieba spływa piękny Anioł } \\
\text { w jasnobrązowej szacie, w aureoli dokoła głowy, z zagiętymi } \\
\text { ostro skrzydłami; prawą ręką wskazuje na skazaną kobietę”. }\end{array}$ \\
\hline 5 & $\begin{array}{l}\text { „Egzekucja żydow- } \\
\text { skiej rodziny przez } \\
\text { spalenie na stosie”. }\end{array}$ & 5 & $\begin{array}{l}\text { „Następna tablica jest powtórzeniem sceny powieszenia świę- } \\
\text { tokradczyni. Osią jest obcięty pień drzewa, do którego przy- } \\
\text { wiązano żydowskiego sklepikarza, jego żonę i dwoje dzieci; } \\
\text { w nogach czwórki palonych wypełzają z drewien stosu pierw- } \\
\text { sze słabe i niskie płomienie; w tle wciąż ten sam krajobraz, } \\
\text { tyle że bogatszy o drzewo owocowe i kilka domków; jeźdźcy } \\
\text { po prawej stronie, garstka pieszych zbrojnych po lewej; naka- } \\
\text { zano im pilnować, by zgodnie z regułami rozpłomienił i wy- } \\
\text { palił się szybko stos, po czym zebrać i powieźć, gdzie trzeba, } \\
\text { gorące jeszcze popioły, aby znikła na zawsze z powierzchni } \\
\text { ziemi rodzina profanatora,z głównym zbrodniarzem na czele”. }\end{array}$ \\
\hline
\end{tabular}




\begin{tabular}{|l|l|l|l|}
\hline 6 & $\begin{array}{l}\text { „Spór między de- } \\
\text { monami i aniołami } \\
\text { o duszę chrześci- } \\
\text { janki”. }\end{array}$ & 6 & $\begin{array}{l}\text { „Przed ołtarzem w tym samym kościele leży na marach } \\
\text { świętokradczyni. Obok jej głowy para Aniołów. Na jej nogach } \\
\text { usiłuje położyć ręce para Diabłów. Walka będzie przewlekła } \\
\text { i ciężka; para Aniołów ma jakby przewagę”. }\end{array}$ \\
\hline
\end{tabular}

W komentarzu do swojego opisu narrator opowiadania Legenda o nawróconym pustelniku upomina się o „tablicę siódmą”, którą zapamiętał z wizyty w Palazzo Ducale. Miała ona przedstawiać „żydowskiego sklepikarza, który kupioną hostię kładzie na ogniu; wytryska z niej krew” (Herling-Grudziński, 2002, s. 35). „Nie pojmuję jej braku w albumie reprodukcji" - dodaje. Ta scena istotnie jest kluczowa i właśnie dlatego od ilustracji z mirakla La rappresentazione d'uno miracolo del corpo di Christo rozpoczęŁam omówienie legendy. Jednakże w omawianym cyklu Uccella podobna scena nigdy nie została wyodrębniona. Gdy zwrócono mu uwagę na lapsus pamięci, pisarz skorygował go w notatce z 17 października 1997 roku w Dzienniku pisanym noca, zacierając zresztą rozróżnienie pomiędzy sobą i narratorem z Legendy o nawróconym pustelniku $u^{41}$.

Błędem byłoby jednak sądzić, co Herling zdaje się czynić w Rozmowach w Neapolu ${ }^{42}$, że krwawiąca hostia została zupełnie pominięta na malowidle Uccella. Jeśli uważnie przyjrzeć się drugiej miniaturze, to po jej prawej stronie, tuż przy ścianie, zobaczymy stojący na podłodze trójnóg z paleniskiem, do złudzenia przypominający ten z drzeworytu w La rappresentazione... ${ }^{43}$

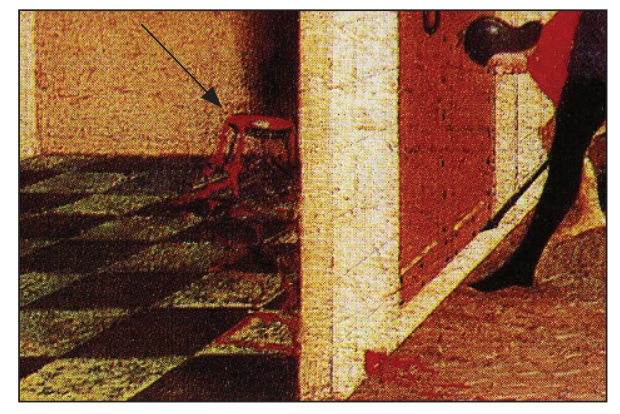

Strzałka wskazuje miejsce, gdzie znajduje się trójnóg z opiekaną na ogniu białą hostią. Spływa z niego krew, przedostaje się przez drzwi i alarmuje strażników. Na barwnym obrazie krew ta jest znacznie lepiej widoczna niż na czarno-białej ilustracji.

41 Zwrócił na to Herlingowi-Grudzińskiemu uwagę Andrzej Kobos (Herling-Grudziński, 2000, s. 119). Podobne zatarcie w rozmowie z Włodzimierzem Boleckim: „nie wiem, jak to się stało, ale wygląda na to, że wymyśliłem sobie w Drugim Przyjściu to siódme tableau, którego chyba w rzeczywistości nigdy nie było” (Herling-Grudziński \& Bolecki, 2000, s. 196).

42 Por. następująca wypowiedź : „W Drugim Przyjściu napisałem też, że Leggenda della’Ostia profanata opowiada dzieje Żyda, któremu jakaś kobieta sprzedała wykradzioną z kościoła Hostię; «opłatek położony na ogniu wytrysnął krwią». Takiej sceny nie ma jednak w cyklu Uccella, jakkolwiek pisząc opowiadanie, byłem przekonany, że widziaŁem ją w Palazzo Ducale. Ale być może trzydzieści lat temu ta scena i ten siódmy obraz cyklu były pozostałościami po jakimś pierwotnym wariancie opowiadania [...]" (Herling-Grudziński \& Bolecki, 2000, s. 196).

43 Trudno zgodzić się z opinią Herlinga-Grudzińskiego, dotyczącą „mieszanych uczuć”, z jakimi Uccello miał malować swój obraz. Swój stosunek do Żydów malarz komunikuje widzowi na dwa sposoby. Po pierwsze, umieszczając nad kominkiem sklepu zastawnika „żydowskie herby”, wśród nich po lewej stronie - skorpion, w centrum - głowa „Murzyna”, trzeci znak nieczytelny (na temat symboliki obu znaków por. Mellinkoff, 1993, indeks tomu 1, hasła: blacks i skin colours: dark, np. ss. 126-127, 156-157, etc.; szczegółowo o skojarzeniu skorpiona i Żydów zob. Bulard, 1935); po drugie, poprzez opozycję drzewa kwitnącego i drzewa suchego, powiązanego z egzekucją chrześcijanki i żydowskiej rodziny, co być może stanowi odsyłacz do Łk13, 9 o nieurodzajnym drzewie figowym i wiąże się z tradycyjną symboliką Eklezji i Synagogi. 
(Zapamiętajmy ten przeskok od hiperwidoczności do niewidzialności kluczowej sceny Legendy o profanacji hostii. Przejście od błędnego wyodrębnienia do fałszywego pominięcia posłuży dalej do sformułowania tezy o acte manqué.)

Opowiadając legendę w Drugim Przyjściu w roku 1961, Herling nie zadaje zbyt wielu pytań: kobieta hostię sprzedała, Żyd ją kupił, opłatek położono na ogniu. Jedyna niejasność dotyczy „siódmej [szóstej] tablicy cyklu”, czyli tego, dlaczego diabły i anioły toczą spór o duszę zdrajczyni. Kwestię tę Herling podkreśla zarówno w swym wczesnym opowiadaniu, jak i po trzydziestu sześciu latach, w Dzienniku pisanym noca, wpis z 15 stycznia 1997 roku: „do dziś zagadką jest siódma [szósta] tablica cyklu, w której o dusze powieszonej toczy spór para aniołów i para diabłów" (15/1/1997 - Herling-Grudziński, 2000, ss. 19-20). W Legendzie o nawróconym pustelniku mówi jeszcze wyraźniej:

„Rzecz jasna istota cyklu spoczywa w ostatniej tablicy. Czy naprawdę jest ciągle zagadką, jak wynika z mojego Drugiego Przyjścia? Pewnie tak, skoro są o tym przekonani uczeni komentatorzy cyklu. Lecz ja sądzę inaczej. Obecność pary Aniołów świadczy, że świętokradczyni wykradła z Kościoła Hostię, ale jej nie sprzedała innowiercy, ofiarowała mu ją, aby na własne oczy ujrzał, czym jest Hostia dla wierzącego chrześcijanina. Stąd Uccello w pojedynku nad zwłokami powieszonej kobiety jest według mnie wyraźnie po stronie Aniołów" (Herling-Grudziński, 2002, s. 36).

Nie znam niestety prac „uczonych komentatorów cyklu”, którzy uważaliby, że właśnie ostatnia miniatura Uccella stanowi zagadkę. Uwaga współczesnych badaczy koncentruje się raczej na fałszywej truth claim całej opowieści, szczególnie zaś na kwestii torturowania hostii (w oczach chrześcijan stanowiącej powtórzenie pasyjnego szydzenia z Jezusa), bo to wiara w jej realność skutkowała śmiercią Żydów. Tej zasadniczej, wydawałoby się, kwestii Herling-Grudziński nie poświęca jednak wcale uwagi, jeśli nie liczyć pojedynczego wtrącenia w nawiasie, nie odnoszącego się zresztą do Żyda: „To wykradziona z kościoła Hostia, przyniesiona (rzekomo) do sprzedania właścicielowi sklepu" (Herling-Grudziński, 2002, s. 34). Ważne są tylko intencje powieszonej:

„Ci, którzy podsycali prześladowania religijne przeciw Żydom, stali na stanowisku, że dokonano świętokradztwa i Bogobójstwa - należało więc zabić tę kobietę, która sprzedała Hostię, oraz tych, którzy Hostię kupili. Ci natomiast, którzy stali na stanowisku przeciwnym, [...] uważali, że ta kobieta wcale nie przyszła sprzedać Hostii, żeby na tym zarobić, lecz jedynie po to, by nawrócić rodzinę żydowskiego kupca. Była zatem, jako chrześcijanka, przekonana o świętości Hostii i przyniosła jedynie po to, by przekonać kupca, że Hostia jest żywym ciaŁem Chrystusa, ukrytym w opłatku" (Herling-Grudziński \& Bolecki, 2000, s. 199).

Trudno nie zauważyć, że to, co Herling nazywa „stanowiskiem przeciwnym”, zanadto przeciwne nie jest, skoro pozostaje w ramach wykładni legendy eucharystycznej. Pisarz wyraźnie nie dostrzega dramatycznie odmiennego jej sensu, z którym systematycznie zapoznawani byli Żydzi, każdy z tryumfów hostii przypłacający życiem, wygnaniem lub przymusową konwersją. Choć deklaruje, że jest to „opowiadanie o prześladowaniach religijnych" (Herling-Grudziński \& Bolecki, 2000, s. 197), w gruncie rzeczy interesują go prześladowania chrześcijan, nie Żydów. Dlatego tylekroć podkreśla „zagadkę siódmej tablicy” i, zgodnie z katolicką nauką o zbawieniu, rozważa przyświecające kobiecie 
intencje. W interpretacji Herlinga legenda o profanacji hostii nie jest mordem sądowym opartym na kłamstwie, tylko chrześcijańską tragedią opartą na nieporozumieniu:

„Tej kobiecie miałoby zatem chodzić o to, żeby kupiec zobaczył krew cieknącą z Hostii i żeby zrozumiał, że jest to żywy Chrystus pod postacią Hostii. I kupiec faktycznie widzi krew cieknącą z Hostii, a więc on, innowierca, otrzymuje w ten sposób widomy znak prawdy chrześcijańskiej. Tymczasem po drugiej stronie drzwi znajdują się żołnierze, którzy widzą wyciekającą krew, co jest dla nich dowodem zbrodni popełnionej przez kupca - czyli sprofanowania Hostii. Bo przecież nic innego nie może im przyjść do głowy. Jest to dla nich powód do wtargnięcia do domu kupca, pojmania go wraz z całą rodziną i spalenia ich wszystkich na stosie" (Herling-Grudziński \& Bolecki, 2000, s. 197).

Wrażenie nieporozumienia pogłębia komentarz Włodzimierza Boleckiego w Rozmowach w Neapolu.

„Uccello pokazuje na tym tableau: Żydzi otrzymali widzialny znak, że żywe ciało Chrystusa znajduje się w płatku Hostii. Ponieważ to tableau podzielone jest na dwie przestrzenie granicą między nimi są drzwi - można to interpretować jako malarskie przedstawienie dramatu niezrozumienia. Po jednej stronie obrazu rodzina żydowskiego kupca widzi cud, bo widzi krew płynącą z Hostii. Równocześnie po drugiej stronie, za drzwiami, znajdują się żołnierze, którzy dowiedzieli się od kogoś tylko tyle, że Hostia została sprofanowana i nie zdają sobie sprawy, że w domu kupca dokonał się cud unaocznienia symboliki chrześcijaństwa" (Herling-Grudziński \& Bolecki, 2000, s. 202).

\section{Od nadwzroczności do przeoczenia}

Z opowiadania Herlinga nie dowiemy się, jak przebiegały wypadki w domu zastawnika. Akt zranienia hostii zupełnie wymazano. To ta sama scena, którą pisarz/narrator najpierw błędnie zapamiętał jako wyodrębnioną na „brakującej” miniaturze Uccella, a następnie równie błędnie usunął z jego obrazu. Ponieważ nadaje ona sens całej opowieści, jej pominięcie przez pisarza można nazwać acte manqué, w dosłownym znaczeniu tego sformułowania. W terminologii francuskiego freudyzmu acte manqué (niem. Fehlleistung) to specjalny typ pomyłki.

„Chodzi o coś, co normalnie wykonujemy bez trudności, a co w jakiejś konkretnej sytuacji albo wzgledem jakiejś szczególnej osoby, z nieznanych powodów się nie udaje. Na przykład ktoś mnie zaprasza na film, na który nie mam ochoty pójść, a ja akceptuję zaproszenie tylko po to, aby mu nie sprawić przykrości. Jadąc do kina, wsiadam jednak do tramwaju jadącego $\mathrm{w}$ przeciwnym kierunku, niż powinnam... W tym sensie akt chybiony (= un acte manqué) jest doskonale udany (= réussi), bo dzięki niemu nie obejrzałam tego okropnego filmu..."44.

To ostatnie zdanie odnosi się wprost do pomyłki Gustawa Herlinga-Grudzinskiego. Akt chybiony jest jednocześnie doskonale udany: zaciemniając powód prześladowania Żydów, możemy o nim mówić, nie dotykając w ogóle jego zasadniczej, bolesnej dla nas

44 To wyjaśnienie, jakie zawdzięczam psychoanalityczce, Małgorzacie Maliszewskiej. Zob. też Abraham, b.d.; Marinesco, b.d.

SLH 3/4 2014/2015 | str. 329 
istoty ${ }^{45}$. Jest to typowe dla strategii literackich Gustawa Herlinga-Grudzińskiego, o których Ewa Bieńkowska pisze, że unikał „zmierzenia się z losem Żydów, przenosząc szybko bohatera we wzorzec głupca Bożego, wędrowca franciszkańskiego, metafory bezdomności i błądzenia człowieczeństwa" (Bieńkowska, 2002, s. 101).

Ten charakterystyczny zabieg pojawia się w kontekście apokryficznego zakończenia Legendy o nawróconym pustelniku, której bohaterem jest właśnie nawrócony Żyd - głupiec Boży. Także i ta historia ma niezaprzeczalnie konfesyjny wydźwięk, trudny do przyjęcia dla niechrześcijanina, szczególnie dla Żyda. W odróżnieniu od podstawowej wersji legendy żydowski profanator z tego apokryfu nie ma ani żony, ani dzieci, odznacza się „atletyczną budową i wielką siłą” i z niewyjaśnionych powodów nienawidzi hostii. Nienawiść (połączona - dodajmy za Trachtenbergiem - „z samobójczą głupotą”6) każe mu wykraść opłatek z wiejskiego kościoła pod wezwaniem św. Franciszka, rozetrzeć hostię w palcach i wdeptać ją w ziemię (Herling-Grudziński, 2002, s. 43). Skazany na stos, dzięki olbrzymiej sile uwalnia się z płomieni, a uniewinniony - „jak uniewinnia się wisielców, którzy oberwali się z szubienicznego stryczka" - na znak nawrócenia pada krzyżem na ziemię. Zostaje wędrowcem-pustelnikiem, niemym świętym Aaronem, któremu „cud ocalenia i nawrócenia odebrał ludzką mowę”. Jego śmierci towarzyszą cudowne zdarzenia: ciało, które wydaje odor sanctitatis, okazuje się tak ciężkie, że para aniołów chcących zabrać je do nieba „zawisa nad umarłym jak dwa obłoki, podobne to do ptaków, to do istot człowieczych". W końcu znika pochłonięte przez swój własny grób, przy wtórze spontanicznie odzywającego się dzwonu (Herling-Grudziński, 2002, s. 44).

Historia jest pięknie opowiedziana, ale brzmi dobrze tylko w chrześcijańskim uchu. Jej punktem kulminacyjnym jest żydowskie nawrócenie. To stanowczo za mało jak na „opowieść o prześladowaniach religijnych” (Herling-Grudziński \& Bolecki, 2000, s. 197), nawet jak na „punkt wyjścia do szukania źródeł strasznych prześladowań wyznawców innej religii, jakich dopuszczali się chrześcijanie" (Herling-Grudziński \& Bolecki, 2000, s. 201). Historia Herlinga to po prostu kolejna gentile's tale, dogadzająca aż nazbyt widocznym upodobaniom konfesyjnym. Jej głuchy dźwięk stanowi tym większy zawód, że jako urodzony w żydowskiej rodzinie Gustaw Herling-Grudziński musiał doskonale wiedzieć, jakie znaczenie dla ukształtowania się żydowskiego etosu martyrologicznego miały legendy o krwi i jak bardzo Żydzi się ich obawiali.

W obu interpretacjach Legendy o sprofanowanej hostii pisarz okazuje się więźniem własnego obrazu świata. Wyczuwalny moralny niepokój pozostaje na poziomie deklaracji. Dla Żyda przewiduje się wciąż te same dwa wyjścia: drogę zbawczej konwersji lub drogę zatracenia. Potężnym symbolem niezrozumiałości/niesłyszalności jego głosu jest

45 Na temat przemilczeń Gustawa Herlinga-Grudzińskiego związanych z jego żydowskim pochodzeniem zob. Bieńkowska, 2002, ss. 99-101.

46 „Tovey przytacza opowieść, jak to w roku 1268, w czasie procesji uniwersyteckiej w Oksfordzie na święto Wniebo"wstąpienia, «pewien Żyd ze skrajnym zuchwalstwem» (nie mówiąc już o samobójczej głupocie) wyrwał przemocą krzyż niosącemu «i podeptał go nogami na znak swej pogardy dla Chrystusa». Jak z hostią, tak i tu, gdybyśmy mieli wierzyć w relacje o tych wypadkach, Żydzi często przejawiali tak straceńczą odwagę. Jeszcze w 1577 roku pewien autor czeski obwinił Żyda, jakoby ten w kościele zerwał krucyfiks i stratował go swymi końmi... na oczach całej zgromadzonej kongregacji!” (Trachtenberg, 1997, s. 107). 
święty Aaron - niemowa. To, co w historii prześladowań religijnych bywa opisywane jako „wyrwany język” ofiar (zob. Tokarska-Bakir, 2004), po stronie słuchaczy można opisać jako zwykłą głuchotę. Jeszcze bardziej wymownym symbolem tej niewrażliwości jest koncept literacki, zgodnie z którym w ostatniej scenie Legendy o nawróconym pustelniku żydowski emigrant Martin, jakby w przymusie powtarzania, wykonuje archetypowy żydowski gest „kłucia hostii” (Herling-Grudziński \& Bolecki, 2000, s. 201)²7.

Literatura, jak to ma w zwyczaju, przekracza tu mens auctoris, zamysł twórczy. Tekst wie i mówi więcej, niż wiedział i chciał powiedzieć jego autor.

\section{Bibliografia}

Abraham, K. (b.d.). L’Acte manqué d'un octogénaire. Pobrano z http://psychanalyse-paris.com/L-Acte-manque-d-unoctogenaire.html

Bieńkowska, E. (2002). Pisarz i los. Warszawa: Zeszyty Literackie.

Bronner, S. J. (Red.). (2007). The meaning of folklore. The analytical essays of Alan Dundes. (S. J. Bronner, Wstęp). Logan, Utah: Utah State University Press.

Bulard, M. (1935). Le Scorpion, symbole du peuple juif. Paris: de Boccard.

Chapeau juif. (b.d.). W Wikipédia. Pobrano z https://fr.wikipedia.org/w/index.php?title=Chapeau_juif\&oldid=113934590

Cohen, J. (1982). The friars and the Jews. The evolution of medieval anti-Judaism. Ithaca, London: Cornell University Press.

Czy prawica zagarnęła Wikipedię? (2013, luty 1). Pobrano 21 lutego 2014, z http://media.wp.pl/kat,1022945,title,CzyprawicazagarnelaWikipedie,wid,15301537,wiadomosc.html?ticaid=1123ef\&_ticrsn=3

Dąbrówka, A. (2001). Teatr i sacrum w średniowieczu. Religia - cywilizacja - estetyka. Wrocław: Funna.

De miraculo hostiae a Judaeo Parisiis anno Domini MCCXC multis ignominiis affectatae. (1968). W Recueil des historiens des Gaules et de la France [Reprint].

Dobrowolski, K. (1928). Przyczynki do dziejów średniowiecznej kultury polskiej. W Studia staropolskie. Księga ku czci A. Brücknera. Kraków: Krakowska Spółka Wydawnicza.

Ganszyniec, R. (1959). Eucharystia w wierzeniach i praktykach ludu. Lud, 44, 75-117.

Gilman, S. L. (1985). Difference and pathology. Stereotypes of sexuality, race, and madness. Ithaca, London: Cornell University Press.

Gilman, S. L. (1986). Jewish self-hatred. Anti-semitism and the hidden language of the Jews. Baltimore, London: The Johns Hopkins University Press.

Górski, K. i in. (Red.). (1965). Rozmyślania dominikańskie (reprint) [oryginat: 1530, Konwent Karmelitanek Klauzurowych, Kraków, ms 287 ] (T. 2). Wrocław, Warszawa, Kraków: Zakład Narodowy im. Ossolińskich.

Greenblatt, S. (2006). Poetyka kulturowa. Pisma wybrane. (K. Kujawińska-Courteney, Red. \& Wstęp). Kraków: Towarzystwo Autorów i Wydawców Prac Naukowych Universitas.

Grudzińska-Gross, I. (2012). Honor, horror i klasycy. Eseje. Sejny: Wydawnictwo Pogranicze.

Guldon, Z., \& Wijaczka, J. (1995). Procesy o mordy rytualne w Polsce w XVI-XVIII wieku. Kielce: Wydawnictwo DCF.

Gustaw Herling-Grudziński. (b.d.). W Wikipedia. Pobrano z https://pl.wikipedia.org/w/index.php?title=Gustaw_Herling-Grudzi\%C5\%84ski\&oldid=42884065

Herling-Grudziński, G. (1990). Drugie Przyjście. W G. Herling-Grudziński, Opowiadania zebrane. Poznań: W Drodze.

47 Na temat czasownika „kłuć” w tym kontekście zob. Tokarska-Bakir, 2008, ss. 155-164. 
Herling-Grudziński, G. (1995). Dziennik pisany nocą 1973-1979. W G. Herling-Grudziński, Pisma zebrane (T. 4). (Z. Kudelski, Red.). Warszawa: Czytelnik.

Herling-Grudziński, G. (1996). Opowiadania zebrane. (Z. Kudelski, Red.) (T. 1). Warszawa.

Herling-Grudziński, G. (2000). Dziennik pisany nocą 1997-1999. W G. Herling-Grudziński, Pisma zebrane. Seria I/ (T. 11). (Z. Kudelski, Red.). Warszawa: Czytelnik.

Herling-Grudziński, G. (2002). Legenda o nawróconym pustelniku. W G. Herling-Grudziński, Pisma zebrane. Seria II (T. 12: Biała noc miłości. Opowiadania, ss. 27-44). (Z. Kudelski, Red.). Warszawa: Czytelnik.

Herling-Grudziński, G., \& Bolecki, W. (2000). Rozmowa X. W Rozmowy w Neapolu. Warszawa: Wydawnictwo Szpak.

Hubicki, S. A. (1602). Zydowskie okrućieństwá nád Naświętszym Sákrámentem y dźiatkámi Chrześćiáńskimi, ku temu przydána iest tychże zdraycow zbrodnia w Swinárowie pod Łośicámi popełniona ktora sądzono na Trybunale Lubelskim Roku Páńskiego 1598, przez Szymoná Alexándrá Hubickiego, Lektorá I. M. X. Biskupá Krákowskiego, W Krakowie, w Drukarni Mikotáiá Szárfenbergerá w Wigilią Národzenia Chrystá Páná Roku 1602, Kraków 1602. Kraków: w Drukarni Mikotáiá Szárfenbergerá.

Jerzy Giedroyć, Melchior Wańkowicz. (2000). Jerzy Giedroyć, Melchior Wańkowicz. Listy 1945-1963 (Aleksandra Ziółkowska-Boehm, Wstęp i wybór). Warszawa: Czytelnik.

Jordan, W. C. (1989). The French monarchy and the Jews. From Philip Augustus to the last Capetians. Philadelphia: University of Pennsylvania Press.

Katz, D. E. (2003). The contours of tolerance: Jews and the Corpus Domini Altarpiece in Urbino. The Art Bulletin, 85(4), 646-661. http://doi.org/http://dx.doi.org/10.2307/3177363

Kipnis, L. (1988). Feminism: A political conscience of postmodernism? W A. Ross (Red.), Universal abandon? The politics of postmodernism. Minneapolis: University of Minnesota.

Kochanowska-Reiche, M. (2000). Mistyczne średniowiecze. Warszawa: Bosz.

Kristeller, P. (1968). Early Florentine woodcuts. London: Holland Press.

Kudelski, Z. (2003, lipiec 5). Gustaw Herling-Grudziński - wątek żydowski. Rzeczpospolita. Pobrano z http://new-arch. rp.pl/artykul/442057_Gustaw_Herling-Grudzinski_-_watek_zydowski.html

Langmuir, G. I. (2002). The tortures of the Body of Christ. W S. L. Waugh \& P. D. Diehl (Red.), Christendom and its discontents. Exclusion, persecution and rebellion, 1000-1500 (ss. 297-298). Cambridge.

Lavin, M. A. (1967). The Altarpiece of Corpus Domini in Urbino. Paolo Uccello, Joos Van Ghent, Piero della Francesca. Art Bulletin, 49(1), 1-24. http://doi.org/http://dx.doi.org/10.2307/3177363

Levene, M. (2000). The limits of tolerance: Nation-state building and what It means for minority groups. Patterns of Prejudice, 34(2), 19-40. http://doi.org/http://dx.doi.org/10.1080/00313220008559138

Lindner, E. G. (2009). Genocide, humiliation and inferiority: An interdisciplinary perspective. W N. A. Robins \& A. Jones (Red.), Genocides by the oppressed. Subaltern Genocide in theory and practice (ss. 140-143). Bloomington, Indianapolis: Indiana University Press.

Magnani, L. (1936). La cronaca di Giovanni Villani. Città Vaticana: Biblioteca Apostolica Vaticana.

Majewski, M. (b.d.). Symbolika szat i insygniów biskupa. Pobrano z http://www.kkbids.episkopat.pl/uploaded/a65/Anamnesis65-4cstr.65-86.pdf

Marcus, I. (1996). Images of the Jews in the Exempla of Cesarius of Heisterbach. W J. Cohen (Red.), From witness to witchraft. Jews and Judaism in medieval Christian thought. Wiesbaden: Harrassowitz.

Marinesco, G. (b.d.). Les actes manqués Introduction à la psychanalyse. Exposé des théories de Freud. Section II. Pobrano z http:/ / www. psychanalyse-paris. com/ Les-actes-manques.html

Masłoń, K. (2012, listopad 24-25). Herling-Grudziński: Ferajna tańczy, ja nie tańczę. Rzeczpospolita/Plus Minus. Pobrano z http://www.rp.pl/artykul/954712.html

Mazurek, R., \& Libera, A. (2013, grudzień 21). Zostałem skrajną prawicą. Pobrano 22 lutego 2014, z http://www.rp.pl/ artykul/365403,1074340-Zostalem-skrajna-prawica.html

SLH 3/4 2014/2015 | str. 332 
Mellinkoff, R. (1993). Outcasted. Signs of otherness in Northern European art of the late Middle Ages. Berkeley, Los Angeles, Oxford: University of California Press.

Nowowiejski, A. (1902). Wykład liturgii Kościoła katolickiego. (T. 2). Warszawa: b.n.

Miłosz, Cz. (1985). Dolina Issy. Warszawa: Świat Książki.

Osier, J.-P. (1984). L'évangelie du ghetto. La légende juive de Jésus du lle au Xe siècle. Paris.

Pilarczyk, K. (2000). Talmud a duchowość żydowska w Polsce XVI i XVII w. W M. Galas (Red.), Duchowość żydowska w Polsce. Materiaty z międzynarodowej konferencji dedykowane pamięci profesora Chone Shmeruka. Kraków: Księgarnia Akademicka.

Porter, B. (2001). The Catholic nation: Religion, identity, and the narratives of Polish history. The Slavic and East European Journal, 45(2), 289-299. http://doi.org/10.2307/3086330

Rubin, M. (1999). The Gentiles tales. The narrative assault on late medieval Jews. New Haven, London: Yale University Press.

Rudnicki, A. (1981). Rogaty warszawiak. Kraków: Wydawnictwo Literackie.

Sandauer, A. (1983). O sytuacji pisarza polskiego pochodzenia żydowskiego w XX wieku (Rzecz, którą nie ja powinienem byt napisać....). Warszawa: Czytelnik.

Schreckenberg, H. (1996). The Jews in the Christian art. An illustrated history. (J. Bowden, Tłum.). New York: Continuum.

Steinberg, E. R., \& Hallstein, C. W. (2003). Probing silences in Joyce's „Ulysses” and the question of authorial intention. James Joyce Quarterly, 40(3), 543-554.

Thompson, S. (1932). Motif-index of folk- literature. A classification of narrative elements in folk-tales, ballads, myths, fables, mediaeval romances, exempla, fabliau, jest-books, and local legends. FF Communications, (106).

Tokarska-Bakir, J. (2004). Ganz Andere? Żyd jako czarownica i czarownica jako Żyd w polskich i obcych źródłach etnograficznych czyli jak czytać protokóły przesłuchań. W M. Janion, C. Snochowska, \& K. Szczuka (Red.), Inny, inna, inne (ss. 110-148). Warszawa: IBL.

Tokarska-Bakir, J. (2008). Legendy o krwi. Antropologia przesądu. Warszawa: W.A.B.

Tokarska-Bakir, J. (2013a). Acte manqué. Gustaw Herling-Grudziński i legenda o krwi. W E. Stankowska, M. Śniedziewska, \& M. Telicki (Red.), «Cienie wielkich artystów». Gustaw Herling-Grudziński i dawne malarstwo europejskie (ss. 113134). Poznań: Wydawnictwo Poznańskiego Towarzystwa Przyjaciół Nauk.

Tokarska-Bakir, J. (2013b). Hassliebe. Żydowska samonienawiść w ujęciu Sandera L. Gilmana (część pierwsza: od Hermana z Moguncji do Johannesa Pfefferkorna). Studia Litteraria et Historica, 2, 27-59. http://doi.org/10.11649/ slh.2013.003

Tokarska-Bakir, J. (2014). Gustaw Herling-Grudziński and the blood libel legend: From overvisibility to oversight. East European Politics \& Societies, 28(4), 739-757. http://doi.org/10.1177/0888325414530150

Trachtenberg, J. (1997). Diabet i Żydzi. Średniowieczna koncepcja Żyda a wspótczesny antysemityzm. (R. Stiller, Tłum.). Gdynia: Uraeus.

Tubach, F. C. (1981). Index exemplorum. A handbook of medieval religious tales. Helsinki: Suomalainen tiedeakatemia.

Yuval, I. J. (2002). „They tell lies: You ate the man”. Jewish reactions to ritual murder accusations. W A. S. Abulafia (Red.), Religious violence between Christian and Jews. Medieval roots, modern perspectives (ss. 86-106). New York: Palgrave Macmillan. 
Gustaw Herling-Grudziński and the blood libel, or is being a Jewish writer compulsory

Abstract: The article concerns Gustaw Herling-Grudziński's medieval stories which explore the theme of blood libel. Despite Grudziński's self-declared sympathy for the libel's Jewish victims, his treatment of the theme is selective and only reflects the Christian perspective. The author then considers possible reasons for such deformation of Grudziński's perception of the stories, locating them in oppression from the nation state, which denies a writer of Jewish origin the right to be at the same time a Polish writer.

Keywords: Gustaw Herling-Grudziński; blood libel; Sander L. Gilman’s notion of Jewish self-hatred; Jewish writer and Polish nationalism

This is an Open Access article distributed under the terms of the Creative Commons Attribution 3.0 PL License, which permits redistribution, commercial and non-commercial, provided that the article is properly cited. wWw.creativecommons.org/licenses/by/3.0/pl

(c) The Author(s) $2014 / 2015$

Publisher: Institute of Slavic Studies PAS [Wydawca: Instytut Slawistyki PAN]

DOI: $10.11649 /$ slh.2015.014

Author: Joanna Tokarska-Bakir, Instytut Slawistyki PAN, Warsaw Correspondence: j.tokarska-bakir@uw.edu.pl

The work has been prepared at author's own expense.

Competing interests: No competing interests have been declared 